ARTICLE HISTORY: Received: September 05, 2021 Accepted: October 28, 2021 Published: November 04, 2021

УДК 621.3

РАЗРАБОТКА УСТРОЙСТВА ДЛЯ ОЧИСТКИ ВОЗДУХА НА ТКАЦКИХ ФАБРИКАХ

Боканова Алия Абылгазиевна Ассоииированный профессор, д.т.н.

Канахина Галия Сабыровна

Стариий преподаватель

Тлеумуратова Кульпан Таттибековна

Магистр физики

Евразийский технологический университет

Мещерякова Татьяна Юрьевна

доиент, к.т.н.

Казахстанско-немеикий университет г.Алматы, Республика Казахстан

\title{
DEVELOPMENT OF A DEVICE FOR AIR PURIFICATION IN WEAVING FACTORIES
}

\author{
Bokanova Aliya Abylgazievna \\ Ass.proffessor, d.t.s. \\ Kanakhina Galiya Sabyrovna \\ Senior lector \\ Tleumuratova Kulpan Tattibekovna \\ Master of physic \\ Eurasian technological university \\ Mechsheryakova Tatyana Yuryevna \\ Ass.professor c.t.s. \\ Kazakh-German University \\ Almaty, Kazakhstan Republic
}

Аннотация. В статье рассматриваются вопросы создания устройств для очистки воздуха прядильного цеха ткацкой фабрики. Из ранее рассмотренных авторы отдают предпочтение устройствам, использующим озонный способ очистки и обеззараживания воздуха. Озонаторное устройство состоит из озонирующего элемента, включающего коронирующий и внешние электроды, разрядные камеры в виде цилиндров. Коронирующий электрод имеет диаметр 50-100 микрон, что является преимуществом по сравнению с зарубежными аналогами.

Abstract. The article discusses the issues of creating devices for cleaning the air of the spinning shop of a weaving factory. Of the previously considered, the authors prefer devices using the ozone method of air purification and disinfection. The ozonator device consists of an ozonizing element, including a corona and external electrodes, discharge chambers in the form of cylinders. The corona electrode has a diameter of 50-100 microns, which is an advantage compared to foreign analogues.

Ключевые слова: озонирующий элемент, коронирующий электрод, разрядная камера, воздух, пыль, микрон, диаметр.

Keywords: ozonizing element, corona electrode, discharge chamber, air, dust, micron, diameter.

Введение. Вопросы охраны труда на современных ткацких фабриках являются одними из важнейших проблем сегодняшнего дня, где главное направление - это очистка рабочей зоны от пыли и токсичных компонентов. На текстильных предприятиях кроме взвешенных частиц в удаленном воздухе присутствуют компоненты мелкодисперсной пыли. Пыль вызывает аллергические реакции, способствует развитию рака. Поэтому разработка аппаратов для очистки воздуха является актуальной.

Основная часть. Авторами предлагается устройство, в котором создают участки коронного разряда разной полярности и соединяют их последовательно. Причем в первом участке обеспечивают зарядку загрязненного воздуха в отрицательном объемном заряде коронного разряда, а во втором участке производят разрядку потока газа в положительном объемном заряде коронного разряда, и затем по значению тока разряда в общей цепи определяют степень запыленности воздуха $[1$, c.31, 2]. В основу устройства для очистки воздуха положены процессы зарядки аэрозольных частиц в результате взаимодействия с отрицательными ионами кислорода атмосферного воздуха, находящимися в отрицательном объемном заряде коронного разряда в первом участке. 
Затем происходят процессы разрядки их в положительном объемном заряде коронного разряда во втором участке, где присутствуют, в подавляющем большинстве, положительные ионы кислорода и азота. Процессы зарядки частиц аэрозоля протекают при столкновении частиц с отрицательными ионами кислорода (перезарядка), которые отдают свои электроны им, тем самым повышая эффективность зарядки аэрозолей газа. Для частиц размером больше 4-8 микрон зарядка их определяется движением отрицательных ионов под действием электрического поля, а частицы диаметром меньше 0,2 микрон, заряжаются главным образом под действием диффузии ионов. Для частиц промежуточного размера 0,2 - 4 микрон необходимо одновременно учитывать оба механизма зарядки: под действием внешнего электрического поля и диффузии [2- 3,с.6]. Эффективность зарядки частиц в потоке воздуха при этом способе зарядки в значительной степени зависит от формы, размеров и природы материала самих частиц аэрозоля. Между тем частицы различных материалов в потоке газа стремятся получить предельный заряд одного знака, соответствующего знаку коронирующего электрода. Поэтому, разница между электрическими зарядами материалов-проводников, полупроводников и диэлектриков оказалась незначительной, а высокая интенсивность зарядки частиц в поле коронного разряда резко снижает требования к выбору характеристик зарядовой зоны коронного разряда. При достаточно узкой ширине зарядовой зоны коронного разряда и скорости потока запыленного газа через разрядный промежуток уже существует зависимость значения тока разряда от степени загрязненности газа.

Для повышения эффективности очистки - используется второй участок коронного разряда с положительным объемным зарядом, который последовательно электрически соединен через коронирующий электрод с первым участком коронного разряда и расположен последовательно с ним по ходу прохождения потока. На рисунке 1 представлена функциональная схема устройства для снижения запыленности атмосферного воздуха.

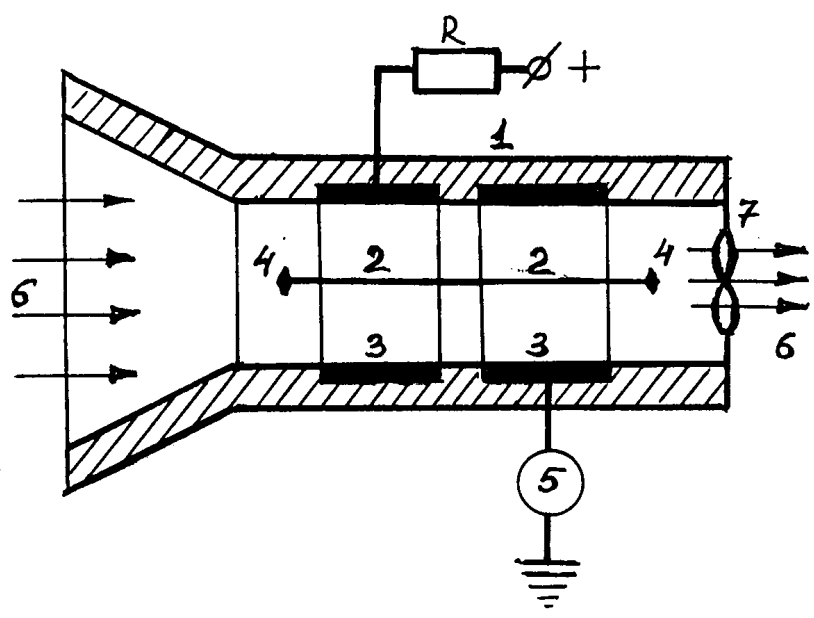

1 -корпус; 2 -коронирующая проволока; 3 -внешние электроды; 4 -держатели; 5 -выходной прибор; 6 -загрязненный газ; 7 -вытяжной вентилятор

Рисунок 1 - Устройство для очистки загрязненности воздуха

Устройство содержит корпус из диэлектрического материала 1, коронирующую проволоку 2 и внешние металлические электроды в виде цилиндров 3. В нашем случае в качестве коронирующего электрода для двух разрядных промежутков служит одна и та же коронирующая проволока 2, закрепленная с двух концов держателями 4. Первый внешний электрод соединен через балластное сопротивление $\mathrm{R}$ с положительным полюсом источника питания, а тогда как второй электрод через выходной прибор 5 заземлен. Для создания равномерного потока загрязненного газа 6 через устройство использован вытяжной вентилятор 7.

При подаче достаточно высокого напряжения на первый внешний электрод, между ним и коронирующей проволокой возникает [2, 4-6,с.265] положительный коронный разряд, в то же время между проволокой и вторым внешним электродом появляется отрицательный коронный разряд. После чего с помощью вытяжного вентилятора загрязненный воздух прогоняется через устройство, где он взаимодействует поочередно сначала с отрицательным, а затем с положительным объемными зарядами разрядных промежутков. В первом разрядном промежутке дисперсные частицы при захвате отрицательных ионов или электронов при перезарядке заряжаются отрицательно и, увлекаясь потоком газа, покидают зону разряда, тем самым уменьшая суммарный ток разряда в общей цепи схемы. Затем отрицательно заряженные частицы попадают в область второго разрядного промежутка, где присутствует зона положительного объемного заряда [1-2]. В этой зоне частицы с отрицательными зарядами рекомбинируют с положительными ионами, нейтрализуются, что опять ведет к 
уменьшению общего разрядного тока. Следовательно, по значению отклонения показания выходного прибора от первоначального (в сторону уменьшения) однозначно определяется степень снижения загрязненности воздуха, продуваемого через устройство.

Устройство имеет следующие параметры: диаметр коронирующего электрода 50 микрон, внешние электроды, в виде цилиндра, имеют диаметр 10мм, ширину 15мм, напряжение питания может меняться в диапазоне от 6,4 до 8,8 кВ, начальный ток коронного разряда составил от 10 до 40 мкА. Ввиду отсутствия калибровочного источника аэрозолей градуировка устройства по концентрации пыли не была произведена. Между тем, контрольные измерения и испытания на згрязненность атмосферного воздуха показали, что устройство имеет высокую чувствительность к высокодисперсной пыли в виде дыма и может использоваться при выполнении сравнительных измерений.

Также авторы разработали схему управления устройством: включения и отключения при повышении концентрации пыли, а также систему электроснабжения (рисунок 2) [6, с.265; 7, с.208; 8, с.233].

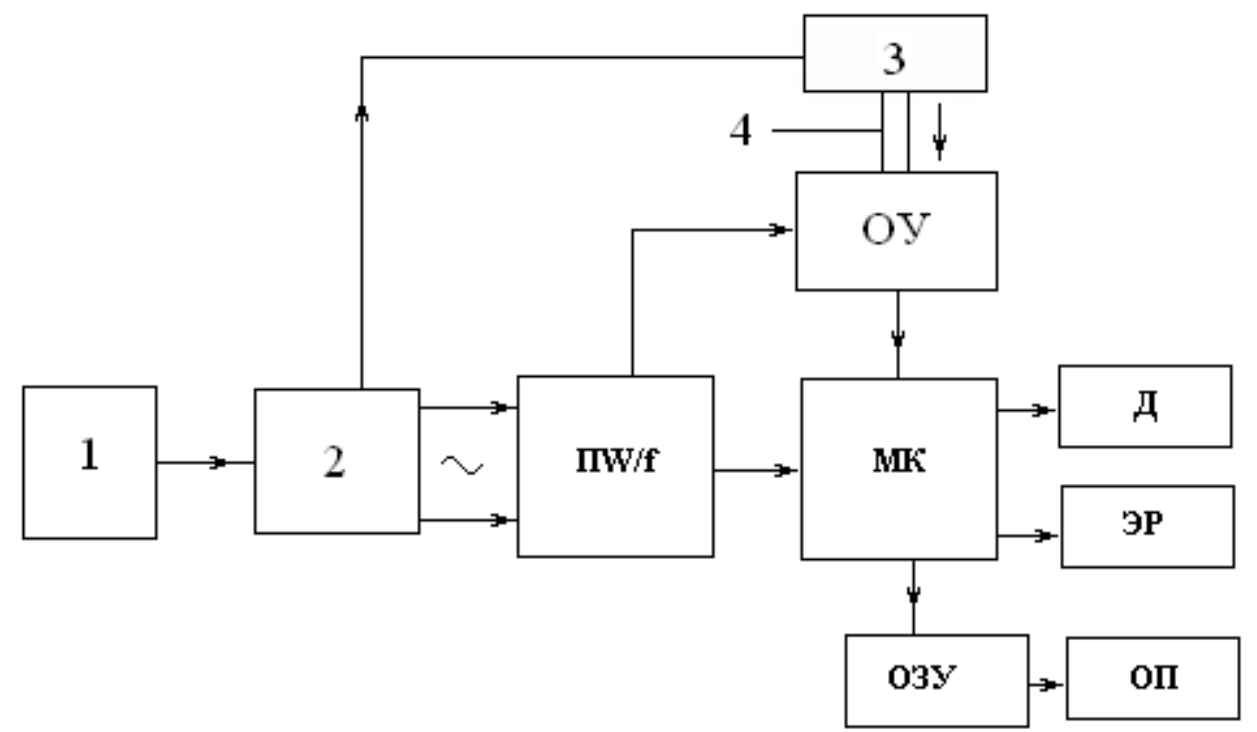

1 -источник электроэнергии; 2 -высоковольтный трансформатор; 3 -компрессор; 4 -воздуховод;

ОУ -озонирующее устройство; ПW/f-преобразователь мощности/частоть; $М$ оперативно-запоминающее устройство; Д-дисплей; ЭР -электронное реле; ОП-оптический порт

Рисунок 2 -Схема управления устройством для очистки воздуха

В качестве источника электроэнергии может служить ветровая электростанция ВЭС или солнечная СЭС, в зависимости от местных условий и расположения фабрики. Использование возобновляемых источников электроэнергии очень удобно для электроснабжения предприятий малого и среднего бизнеса, расположенных в селах, районах, удаленных от основных ЛЭП. Компрессор 3 нагнетает атмосферный воздух в озонирующее устройство ОУ $[6,9-10$, с.4].

\section{Список литературы}

1. Абишова А.С., Боканова А.А, Мустафаева Н.М. Исследование процессов зарядки хлопковых волокон в поле коронного разряда. -Алматы, 2013. -Вестник АУЭС. -№2. - С.31-34.

2. Абишова А.С., Бахтаев Ш.А., Боканова А.А. Устройство для контроля запыленности газа./ Предпатент РК №16503. опубл. 15.11.2005: Бюл. №11.-2 с: ил.

3. A. Abdurrahmanov, A. Bokanova, A. Abishova, K.Tleumuratova. Criteria of comparative estimation of ozonizers. Science and education in XXI century. -Montana,USA. 2014 - P.6. (inEng.).

4. Parpiev M. P., Simonov A. A., Fatkhullaev A. The use of ozone and micro bubble technologies for cultivating chlorella// European Journal of Technical and Natural Sciences. - Vienna, Austria. 2020 , № 3. P. 24 -28.

5. Simonov A. A., Parpiev M. P., Abdurakhmanov O. Kh., Asilova F. Calculations of the dynamic concentration of ozone in the premises// Materials of the international scientific and practical Internet conference "Trends and Prospects for the development of science and Education in the context of globalization", Ukraine, Pereyaslav-Khmelnitsky, 2019, Issue $45,-$ p. 504-506.

6. Боканова А.А., Канахина Г.С., Ермаханова Ф.Р., Мещерякова Т.Ю., Тлеумуратова К.Т. Выбор системы электроснабжения озонаторного комплекса для очистки воды Большого Алматинского озера//У1 НМПК 
«Членство в ВТО: перспективы научных исследований и международного рынка технологий», Монреаль (Канада), 20-22 октября 2021 г. -С.265-274.

7. BahtaevSh.A., Bochkareva G.V., Musapirova G.D. (2017) Non-contact measurement meters of micro-sizes on coronary discharge. News of National Academy of sciences of the Republic of Kazakhstan. Series of geology and technical sciences ISSN 2224-5278. Vol.4. Number 424 (2017). P.208. (inEng.).

8. AbdurrahmanovA.A.,Bahtaev S.A., Bokanova A.A., Mataev U. Device for purification of airs of poultry plants. News of National Academy of sciences of the Republic of Kazakhstan. Series of geology and technical sciences ISSN 2224-5278. Vol.4. Number 424 (2017). P.233-236. (inEng.).

9. A.Toigozhinova, Sh.A.Bakhtaev, Sh. Koshimbaev (2015) To Research and Development of system elements of automatic control and regulation of ozone concentration in enclosed space. Research Jr. of applied Sciences 10(12), P.947-955. ISSN: 1815-932X. (in Eng.)

10. Паулин О.Н. О функциональной полноте элементов управления вычислительными процессами. Одесса: Научный взгляд в будущее. 4:4. C.4. ISSN 2415-7656X. https://doi.org/10.21893/2415-7538-2016-04-4-18.

\section{References:}

1. Abishova A.S., Bokanova A.A., Musthashaeva N.M. Investigation of cotton fiber charging processes in the corona discharge field. -Almaty, 2013. -Vestnik AUETc. -№2. - P.31-34. (In Russian).

2. Abishova A.S., Bahtaev Sh.A., Bokanova A.A. Gas dust control device./ Innovative Patent of Republic of Kazakhstan №16503, Bull. №11, 15/11/2005. (In Russian).

3. A. Abdurrahmanov, A. Bokanova, A. Abishova, K.Tleumuratova. Criteria of comparative estimation of ozonizers. Science and education in XXI century. -Montana,USA. 2014 - P.6.

4. Parpiev M. P., Simonov A. A., Fatkhullaev A. The use of ozone and micro bubble technologies for cultivating chlorella// European Journal of Technical and Natural Sciences. - Vienna, Austria. 2020, № 3. P. 24 -28.

5. Simonov A. A., Parpiev M. P., Abdurakhmanov O. Kh., Asilova F. Calculations of the dynamic concentration of ozone in the premises// Materials of the international scientific and practical Internet conference "Trends and Prospects for the development of science and Education in the context of globalization", Ukraine, Pereyaslav-Khmelnitsky, 2019, Issue 45, p.p. 504-506.

6. Bokanova A.A., Kanakhina G.S., Ermahkanova Ph.R., Myrzabekova A.M., Mechsheryakova T.Y., Tleumuratova K.T. Selection of the power supply system of the ozonator complex for water purification of the Big Almaty Lake //Materials of the VI International Scientific-Practical Conference: Membership in the WTO: Prospects of Scientific Researches and International Technology Market, Monreal (Canada), October 20-22, 2021, P.265-274.

7. Bahtaev Sh.A., Bochkareva G.V., Musapirova G.D. (2017) Non-contact measurement meters of micro-sizes on coronary discharge. News of National Academy of sciences of the Republic of Kazakhstan. Series of geology and technical sciences ISSN 2224-5278. Vol.4. Number 424 (2017). P.208. (inEng.).

8. AbdurrahmanovA.A.,Bahtaev S.A., Bokanova A.A., Mataev U. Device for purification of airs of poultry plants. News of National Academy of sciences of the Republic of Kazakhstan. Series of geology and technical sciences ISSN 2224-5278. Vol.4. Number 424 (2017). P.233-236. (inEng.).

9. A.Toigozhinova, Sh.A.Bakhtaev, Sh. Koshimbaev (2015) To Research and Development of system elements of automatic control and regulation of ozone concentration in enclosed space. Research Jr. of applied Sciences 10(12), P.947-955. ISSN: 1815-932X. (in Eng.)

10. Paulin O. N. On the functional completeness of the control elements of computational processes. - Odessa: A scientific look into the future. - Vol. 4. - No. 4. - p. 4-8. (in Russian). 